Pesq. Vet. Bras. 37(12):1385-1394, dezembro 2017 DOI: $10.1590 / \mathrm{S} 0100-736 \mathrm{X} 2017001200005$

\title{
Specific immune response in neonate Holstein heifer calves fed fresh or frozen colostrum ${ }^{1}$
}

\author{
Sylvia M.F. Novo², Juliana F. dos R. Costa를 Camila C. Baccili² ${ }^{2}$ Natália M. Sobreira², \\ Milena A. Maia ${ }^{2}$, Stephanie B.P. Leite ${ }^{2}$, David J. Hurley ${ }^{3}$ and Viviani Gomes ${ }^{2 *}$
}

\begin{abstract}
Novo S.M.F., Costa J.F.R., Baccili C.C., Sobreira N.M., Maia M.A., Leite S.B.P., Hurley D.J. \& Gomes V. 2017. Specific immune response in neonate Holstein heifer calves fed fresh or frozen colostrum. Pesquisa Veterinária Brasileira 37(12):1385-1394. Departamento de Medicina Interna, Faculdade de Medicina Veterinária e Zootecnia, Universidade de São Paulo, Av. Prof. Dr. Orlando Marques de Paiva 87, Cidade Universitária, Butantã, São Paulo, SP 05508-270.E-mail: viviani.gomes@usp.br

The objective of this study was to evaluate the influence of viable cells from colostrum on immune development in dairy heifer calves during the first 28 days of life. The animals were distributed between 2 groups: $\mathrm{COL}+(\mathrm{n}=9)$ receiving fresh whole colostrum from their own damns; and COL- $(\mathrm{n}=10)$ receiving pooled frozen colostrum, containing no viable cells, from a pool of donor cows. These calves were assessed before colostrum intake (D0), 48 hours of age (D2), and weekly from D7 to D28. The development of immunity was evaluated by assessment of the phenotype of blood leukocyte subsets, and induced cytokine production after 72 hours of stimulation in culture with concanavalin A (ConA), killed Staphylococcus aureus (S.aureus) and killed Escherichia coli (E. coli) by peripheral blood mononuclear cell (PBMC). The clinical history of these calves was marked by a high frequency of diarrhea in both groups. However, COL- had greater diarrhea intensity scores (fecal score 3 of 4), and rectal temperature on D7 than COL+ calves. Moreover, bronchopneumonia $(\mathrm{n}=1)$ and navel inflammation were observed only in COL- calves. COL- had a lower concentration of serum iron, and a higher absolute number of lymphocytes on D7 than COL+. COL- also had a higher percentage of anemic calves than the COL+ calves on D21 and D28. In general, the percent of cells within each subset of leukocytes was similar between the groups over the experiment, except on week 1 when COL- calves had a higher percentage of lymphocytes expressing $\mathrm{CD} 45 \mathrm{RO}^{+}(\mathrm{P}=0.07)$. A steady increase in $\mathrm{CD} 45 \mathrm{RO}^{+}$ and concomitant decline in CD45RO- leukocytes was observed over the course of the study, indicating the development of immune memory. The proportion of CD14MHCII+ leukocytes increased with age $(\mathrm{P} \leq 0.05)$. The median background cytokine production by PBMC that were not stimulated was below the level of detection of the assays used for both groups. The PBMC from COL+ calves stimulated with ConA secreted a larger quantity of IL-17 week $2(\mathrm{COL}+=2060.0 \mathrm{pg} / \mathrm{mL}$ and $\mathrm{COL}-=0.0 \mathrm{pg} / \mathrm{mL}, \mathrm{P}=0.00)$. PBMC from COL+ calves stimulated with killed $S$. aureus whole cell antigen $(\mathrm{P}=0.05)$ and killed $E$. coli whole cell antigen $(\mathrm{P}=0.05)$ also secreted higher levels of IL17 than COL- calves at week 4. Clear production of IL17 was observed in PBML from COL+ calves at week 2, but the difference was not statistical different between groups. In conclusion, calves fed fresh and frozen colostrum showed no difference in cells subset profile overall. The increased percentage of leukocytes expressing the memory $\mathrm{CD} 45 \mathrm{RO}^{+}$or $\mathrm{CD} 14 \mathrm{MHCII}^{+}$over the course of the experiment indicated a maturation of the adaptive immune response after natural exposure to pathogens in the
\end{abstract}

\footnotetext{
${ }^{1}$ Received on September 29, 2016.

Accepted for publication on April 10, 2017.

${ }^{2}$ Departamento de Medicina Interna, Faculdade de Medicina Veterinária

e Zootecnia, Universidade de São Paulo, Av. Prof. Dr. Orlando Marques de
} 
environment of the calf. The enhanced IL17 secretion by COL+ calves indicated that viable maternal cells modulated T-cell Th17 production that was primed by bacterial antigens. This mechanism could be responsible for quick and efficient activation of neutrophils for bacterial clearance. The differences in cytokine production observed between groups may help to explain the different clinical pictures observed for calves COL+ and COL- calves.

INDEX TERMS: Immune response, neonate calves, colostrum, passive immune transfer, lymphocytes subsets, cytokines.

RESUMO.- [Resposta imune específica em bezerras
holandesas recém-nascidas alimentadas com colostro
fresco ou congelado.] O objetivo desta pesquisa foi avaliar a influência das células do colostro no desenvolvimento imune em bezerras leiteiras durante os primeiros 28 dias de vida. Os animais foram distribuídas em 2 grupos: COL+ $(\mathrm{n}=9)$ recebeu colostro fresco de suas próprias mães; e COL- $(\mathrm{n}=10)$ recebeu pool de colostro congelado sem células viáveis oriundo de vacas doadoras. Estas bezerras foram avaliadas antes da ingestão do colostro (D0); às 48 horas (D2) e semanalmente entre o D7 e D28. 0 desenvolvimento da imunidade foi avaliada pela fenotipagem das subpopulações celulares do sangue e produção de citocinas pelas células mononucleares sanguíneas após 72 horas de estimulação com concanavalina A (ConA), Staphylococcus aureus (S. aureus) e Escherichia coli (E. coli) inativadas. 0 histórico clínico das bezerras foi marcado por elevada frequência de diarreias em ambos os grupos. Entretanto, COL- apresentou maior intensidade de diarreia (escore de fezes $\sim 3$ de 4 ) e maior temperatura retal no D7 do que as bezerras COL+. Além disso, broncopneumonia ( $n=1)$ e inflamações umbilicais foram diagnosticadas apenas nas bezerras COL-. 0 grupo COL- apresentou menor concentração de ferro sérico e maior número de linfócitos no D7 do que o grupo COL+. COL- também apresentou maior frequência de anemias que o grupo COL+ no D21 e D28. Em geral, a fração das subpopulações celulares foram semelhantes entre os dois grupos ao longo do tempo estudado, exceto na semana 1 , onde as bezerras COL- apresentaram maior proporção de CD45RO ${ }^{+}$ $(\mathrm{P}=0.07)$. Observou-se um constante aumento de $\mathrm{CD} 45 \mathrm{RO}^{+}$ com declínio concomitante de CD45RO- ao longo do estudo, indicando o desenvolvimento da resposta imune. A proporção de células CD14MHCII+ aumentou de acordo com a idade $(\mathrm{P} \leq 0.05)$. As medianas das citocinas produzidas a partir do PBMC não estimuladas apresentaram valores abaixo do nível de detecção em ambos os grupos. O PBMC do COL+ estimulado com ConA secretou elevada concentração de IL17 na semana $2(\mathrm{COL}+=2060.0 \mathrm{pg} / \mathrm{mL}$ e COL $=0.0 \mathrm{pg} / \mathrm{ml}$, $\mathrm{P}=0.00)$. $\mathrm{PBMC}$ do $\mathrm{COL}+$ estimuladas com $S$. aureus inativado $(\mathrm{P}=0.05)$ e $E$. coli inativada $(\mathrm{P}=0.05)$ secretaram níveis mais elevados de IL17 que as bezerras COL- na semana 4. Outros picos de IL17 foram observados no COL+ na semana 2, porém não foi possível detectar diferenças estatísticas entre os grupos. Conclui-se que as bezerras alimentadas com colostro fresco e congelado apresentaram perfil similar entre as proporções das subpopulações celulares. 0 aumento de células expressando os marcadores de memória $\mathrm{CD}_{45 \mathrm{RO}^{+}}$e $\mathrm{CD} 14 \mathrm{MHCII}^{+}$demonstram, ao longo do experimento, o amadurecimento do sistema imune específico das bezerras após estimulação natural por patógenos após o nascimento. A maior secreção de IL17 pelas células das bezerras COL+ indica que as células maternas podem modular resposta imune Th17 direcionada aos antígenos bacterianos. Este mecanismo poderia ser responsável pela rápida e eficiente quimiotaxia de neutrófilos e eliminação dos microrganismos bacterianos. Os diferentes perfis de citocinas podem ser responsáveis pelos diferentes históricos clínicos relatados para as bezerras COL+ e COL-

TERMOS DE INDEXAÇ̃̃̃: Bezerras recém-nascidas, colostro, transferência de imunidade passiva, subpopulações de linfócitos, citocinas.

\section{INTRODUCTION}

At birth calves are considered naïve and have been demonstrated to be agammaglobulinemic due to the thick and essentially impenetrable synepitheliochorial placenta. Neither the most of pathogens nor immune factors pass freely across during pregnancy of the cows. Despite maintaining the essential sterility of fetal environment, this isolation of the fetus has two negative consequences: the calf is born with no circulating maternal or induced locally produced antibody, and the calf develops no immunological memory before birth (Barrington \& Parrish 2001).

Colostrum, rich in IgG1, leukocytes and cytokines, is the sole source of maternal immune transfer for the neonate. These immune elements promote the survival of the calf over the first 3-4 weeks after birth. The role of colostral antibodies is well established. However the role of maternal cells transferred with colostrum on neonatal immune development is not yet well defined (Langel et al. 2015).

Bovine colostrum typically contains between $1 \times 10^{6}$ and $2.5 \times 10^{6}$ somatic cells $/ \mathrm{mL}$ (Liebler-Tenorio et al. 2002, Gomes et al. 2011). About $30 \%$ of these cells are viable (Godden et al. 2012). Macrophages (32.7\%) are the predominant cell type found in colostrum. In addition, T cells (25.4\%) and B cells (2.9\%) make up the majority of the remaining cells (Meganck et al. 2014).

Colostral leukocytes pass across the gut epithelium of neonate calves. Maternal cells have been detected in the circulation, Peyer's patches and a variety of lymph nodes of neonatal calves after 24 to 96 hours relative to ingestion of colostrum (Aldridge et al 1998, Liebler-Tenorio et al. 2002, Reber et al. 2006).

Adoptive transfer of antigen-specific cells from colostrum may function in the immediate clearance pathogens from mucosal surfaces and infected tissues (Langel et al. 2015). Researchers have demonstrated that maternal leukocytes transferred to the neonatal calf have the ability to respond to several antigens (Reber et al. 2005, Donovan et al. 2007, Reber et al. 2008a, 2008b).

Calves fed whole colostrum containing viable maternal cells $(\mathrm{COL}+)$ mounted stronger innate and adaptive im- 
mune response than calves fed acellular colostrum (COL-) (Riedel-Caspari \& Schmidt 1991a, 1991b, 1991c, 1991d). At this time, we are aware of only five papers published on the impact of transferred maternal cells on calf immune development (Reber et al. 2005, 2006, 2008a, 2008b, Langel et al. 2015).

Evidence supporting the hypothesis that maternal cells specifically enhance immune development is provided by: 1) an increased number of circulating blood lymphocytes in calves receiving viable maternal cells with colostrum; 2) enhanced proliferative response to antigen, superantigen and mitogens by calf peripheral blood mononuclear cells after feeding colostrum with viable maternal cells; and 3) enhanced antibody production after stimulation with antigen in calves receiving viable maternal cells (Riedel-Caspari \& Schmidt 1991a, 1991b, Donovan et al. 2007). Moreover, COL+ calves had a higher percentage of lymphocytes expressing activation markers (CD25, CD26, CD172a) than COL- calves (Reber et al. 2006, 2008a, 2008b, Langel et al. 2015). In contrast, feeding calves fresh colostrum suppressed B cells differentiation in the mesenteric lymph nodes relative to colostrum deprived calves (Aldridge et al. 1998).

The hypothesis of this study is that viable cells transferred with colostrum (and the products they subsequently make in the neonate) contribute to the development of innate and adaptive immunity in the neonatal calf. Therefore, the objective of this research was to evaluate the effect of viable cells received in colostrum on the development of immunity in calves during the first 4 weeks of life.

\section{MATERIALS AND METHODS}

\section{Farm and animals}

This research was approved by University of Sao Paulo Animal Care and Use Committee number nํ2934/2013. The experiment was conducted on a commercial farm in Sao Paulo, Brazil from July to October of 2014.

Holstein cows were moved from dry-cow pasture to the maternity barn 30 days before the expected delivery date. A team of the research veterinarians monitored the birth of the calves to assure that no natural suckling occurred. Healthy calves, from uncomplicated deliveries, were included in the study. These calves were verified to be healthy based on a clinical examination (described below).

Holstein heifer calves were distributed in two groups: COL+ $(n=9)$ that received fresh, whole colostrum containing viable maternal cells from their own damns, and COL- $(n=10)$ that received pooled frozen colostrum containing no viable cells prepared from donor cows.

Dams and donors were milked immediately after delivery using a portable milking machine housed in the maternity unit. Colostrum was collected after cleaning teats with soap and water, dipping them in a $1 \%$ iodine solution and drying them with clean paper towels. Both groups received colostrum of the similar quality based on the immunoglobulin concentration measured using a colostrometer $(70-120 \mathrm{~g} / \mathrm{L})$ and total solids using a Brix refractometer $\left(23-32^{\circ}\right)$. Historically, the median somatic cell count of fresh colostrum in this herd, obtained using a direct microscopic count, was $1.9 \times 10^{6} / \mathrm{mL}$ (Gomes et al. 2011).

Donor colostrum (4L per calf) was stored frozen at $-20^{\circ} \mathrm{C}$ in plastic $2 \mathrm{~L}$ bottles for a period of 24 hours to 3 months before use. Calves were fed twice. The first bottle was slowly warmed to $37^{\circ} \mathrm{C}$ in a water bath, and fed to COL- calves within 3 hours of birth. A second bottle was fed about 6 hours later. After thawing, an aliquot of $20 \mathrm{~mL}$ was diluted 1:1 with Phosphate Buffer Saline (PBS) and centrifuged at $800 \mathrm{xg}, 4^{\circ} \mathrm{C}$ by 15 minutes. The centrifugation provided a pellet containing residual cells and cell fragments. The cells were washed in $20 \mathrm{ml}$ of PBS, and the viability was assessed using Trypan blue stain. No whole, viable cells were recovered from any frozen colostrum used in this research.

COL+ calves were fed within 6 hours after birth. A bottle containing two litters of fresh colostrum from the dam was utilized. A second $2 \mathrm{~L}$ bottle of whole colostrum was held at $4^{\circ} \mathrm{C}$ until a second feeding. It was warmed to $37^{\circ} \mathrm{C}$ and fed 6 hours later.

All calves utilized in this study had adequate levels of serum protein after colostrum consumption (5.6-9.7 g/dL) based on total protein measured with a refractometer. The total protein measurement was done at 48 hours of age.

All COL- and COL+ calves were moved to individual pens. The calves were maintained in this housing continuously for 4 weeks. Routine farm management was applied to all aspects of calf rearing not specifically defined under the study protocol. Subsequent to colostrum feeding, calves received 6 liters of milk from the dairy herd per day. Half of the milk was given in the morning and half in the evening. They were started on calf ration (Rumileite $20^{\circledR}$, Guabi) at 2 weeks of age, and provided water ad libitum.

\section{Clinical assessment of the calves}

The incidence of diarrhea in both treatment groups was higher than in typical dairy calves. It was observed that $78 \%$ of the COL+ calves had diarrhea, and $70 \%$ of the COL- calves had diarrhea during the 28-day course of this study. The cases of diarrhea peaked on week 1 and 2. COL- calves appeared to develop more severe diarrheal disease than COL+ calves. The COL- calves had a more rapid respiratory rate and higher rectal temperature during the 2nd week of the study than the COL+ calves. Hematological examination showed anemia and hypoferremia in the COL- calves during third and fourth week of the study. Only one calf, from COLgroup, was diagnosed with bronchopneumonia. This occurred on week 3. Navel inflammation was observed in three COL- calves, but none of the COL+ calves were affected. (N.B. -A complete documentation the clinical findings and description of the nature of the gastrointestinal disease data can be found in "Effect of maternal cells transferred with colostrum on the health of neonatal calves" (Novo et al. 2017).

\section{Blood samples}

Blood samples were collected before colostrum intake (D0); between 24 and 48 hours (D2); 1 week (D7); 2 weeks (D14); 3 weeks (D21) and 4 weeks after birth (D28). A total of sixty milliliters of blood was collected from each calf in a syringe containing $1.5 \mathrm{~mL}$ Ethylenediaminetetraacetic acid (EDTA, 100mM) for the isolation of peripheral blood mononuclear cells (PBMC). In addition, four milliliters of blood was collected in vacutainer tubes containing $7.4 \mathrm{mg}$ of EDTA as a source of cells for phenotyping assays.

\section{Phenotyping}

The phenotypic analysis of blood leukocytes was evaluated using bovine-specific monoclonal antibodies for cell surface receptors associated with differentiation and function. Antibodies concentrations were optimized using a step-wise dilution series. The lowest concentration of antibody yielding saturating (peak) signal intensity was used for each antibody (Table 1).

One hundred microliters of whole blood was distributed into individual tubes for each staining condition. The red blood cells were lysed using nine hundred microliters of FACSLyse solution 
in according with recommendations of manufactured (BD Biosciences, San Jose, CA, USA). The samples were centrifuged 290xg for 8 minutes at $4^{\circ} \mathrm{C}$, and the supernatant was discarded. The cells were suspended in $1 \mathrm{~mL}$ of Phosphate Buffered Solution (PBS) and washed by centrifugation of samples $(290 \mathrm{xg})$ for 8 minutes at $4^{\circ} \mathrm{C}$. This suspension and centrifugation was repeated.

The cells were incubated with one hundred microliters of each primary antibody diluted in PBS as indicated in Table 1 for 30 minutes at $4^{\circ} \mathrm{C}$. The cells were washed three times with PBS and subsequently incubated with one hundred microliters of solution containing conjugated isotype-specific secondary antibodies (as specified in Table 1) for 30 minutes at $4^{\circ} \mathrm{C}$. The IgG1 specific detection antibody was conjugated with PE and the IgG2 specific detection antibody conjugated with FITC. The cells were washed twice in PBS. Finally, the cells were suspended in $300 \mu \mathrm{L}$ of cold, sterile PBS.

For the purpose of these trials, each of the isotype specific detection antibodies was titrated to establish the minimal saturating concentration required to provide optimal single color and dual color expression of the primary markers used in the experiment in a preliminary trial.

Samples were analyzed by flow cytometry using a FacsCalibur cytometer (BD Biosciences, San Jose, CA, USA). Forward angle scatter and $90^{\circ}$ light scatter gate windows were established to discriminate between small, large, granular and agranular leukocyte populations.

Flowjo analysis software (Treestar Inc., San Carlos, USA) was used to parse and analyze the labeled cells within the leukocyte populations from each sample. At least 10,000 cells (in the total leukocyte primary gate) were analyzed per sample. All samples were gated based on forward angle and side scatter to establish two primary regions: i.e. monocytic cells and lymphocytes. During the course of this study, the calves enrolled had few detectable monocytes. It was not possible to identify a specific monocyte region by size and granularity in most of the two-parameter histograms. For those samples, the expression of CD14 and MHCII was analyzed using the total mononuclear leukocyte region in forward angle and side scatter. The lymphocyte population was analyzed for the expression of specific fluorescence for CD45, CD45RO, CD3 and gamma-delta (GD) cells.

\section{Cytokines production}

Cell cultures for induction of cytokines were set up on weeks 1 through 4. No cultures were setup for D0 or D2 due an inadequate recovery of $\mathrm{PBMC}$ from blood in those samples.

Isolation of peripheral blood mononuclear cells (PBMC). PBMC were isolated from $60 \mathrm{~mL}$ samples of venous blood. First, whole blood was distributed in four tubes $(15 \mathrm{~mL}$ each) to obtain buffy coats by centrifugation $(800 \mathrm{xg})$ for 20 minutes at $4{ }^{\circ} \mathrm{C}$. The buffy coats from all four tubes were pooled in a single tube. The tube was filled to $50 \mathrm{~mL}$ of sterile PBS. The buffy coat cells were centrifuged $\left(800 \mathrm{xg}\right.$ ) for 10 minutes at $4^{\circ} \mathrm{C}$ to remove platelets and plasma. The supernatant was discarded, and the cells were suspended with $50 \mathrm{~mL}$ of sterile PBS, centrifuged under the same conditions twice more. Finally, cells were suspended in $40 \mathrm{~mL}$ of sterile PBS. To obtain PBMC the cells were layered over a single-step density separation medium as described by Reber et al. (2005). Needles (18 gauge) were attached to sterile syringe barrels $(60 \mathrm{~mL})$ used as a controlled layering device. Each syringe barrel was placed at a slant in the mouth of $50 \mathrm{~mL}$ centrifuge tubes containing $10 \mathrm{~mL}$ of a single-density gradient $1.083 \mathrm{~g} / \mathrm{mL}$ (Histopaque, Sigma, USA). The cellular suspension $(40 \mathrm{~mL})$ was placed slowly into the syringe. The suspension slowly formed a layer over the density gradient medium. Tubes were centrifuged (750xg) for 30 minutes at $4^{\circ} \mathrm{C}$. The mononuclear cells were re- moved from the interface between the PBS and density gradient medium where they formed a distinct band. The recovered mononuclear cells were placed in a $50 \mathrm{~mL}$ sterile tube then the tube was filled to $50 \mathrm{~mL}$ with PBS. The cells were pelleted by centrifugation $800 x$ f for 5 minutes. The supernatant was discarded. Remaining red blood cells were lysed by addition of $2 \mathrm{~mL} 0.2 \%$ saline solution for 20 seconds with continuous agitation, immediately followed by $2 \mathrm{~mL} 1.6 \%$ of saline solution. The tube was filled to $50 \mathrm{~mL}$ with sterile PBS. The tubes were centrifuged $(800 \mathrm{xg}$ ) for 5 minutes at $4^{\circ} \mathrm{C}$. The lysis procedure was repeated a second time. After lysis, the PBMC were washed twice and finally suspended in $1 \mathrm{~mL}$ of RPMI-1640 (Sigma, USA) supplemented with 10\% fetal serum bovine, $2 \mathrm{mM}$ L-glutamine, $60 \mu \mathrm{g} / \mathrm{mL}$ of penicillin and $20 \mathrm{mM} \mathrm{HE}-$ PES buffer. The cells were counted using a hemacytometer after dilution in trypan blue to determine the number of viable cells. The cells were suspended to a concentration of five million live $\mathrm{PBMC} / \mathrm{mL}$.

IFN-gamma and IL17 secretion by PBMC stimulated with antigens. PBMC were added to four wells of a sterile 96-well round-bottom plate for each treatment condition tested at 200 microliters per well. Sets of wells for each preparation of PBMC were prepared with $50 \mu \mathrm{L}$ of killed Staphylococcus aureus $\left(1.5 \times 10^{9}\right.$ $\mathrm{CFU} / \mathrm{mL}), 50 \mu \mathrm{L}$ of killed Escherichia coli $\left(1.5 \times 10^{9} \mathrm{CFU} / \mathrm{mL}\right), 50 \mu \mathrm{L}$ of concanavalin A $(20 \mu \mathrm{g} / \mathrm{mL})$, and $50 \mu \mathrm{L}$ of RPMI-1640 medium (negative control). Staphylococcus aureus and Escherichia coli were originally isolated from two different cows with clinical mastitis and prepared in our laboratory. The antigens were prepared by culture of each bacteria in liquid Brain Heart Infusion (BHI) for 18 hours at $37^{\circ} \mathrm{C}$. The bacterial cultures were centrifuged to produce a pellet at $1600 \mathrm{xg}$ for 30 minutes. The culture medium was removed and the pellet was washed twice using sterile PBS. The concentration of antigens was adjusted comparing the turbidity of the bacteria suspension with a McFarland standard. The bacteria was killed by heating to $60^{\circ} \mathrm{C}$ for $1.5 \mathrm{~h}$, after washed with PBS before being suspended to their original volume.

The plates containing the $\mathrm{PBMC}$ were incubated at $37^{\circ} \mathrm{C}$ in $\mathrm{CO}_{2}$ incubator for 72 hours. After incubation, the plates were centrifuged at $200 \mathrm{xg}$ for five minutes. From each well, the supernatant was harvested and collected in labeled $1.5 \mathrm{~mL}$ microcentrifuge tubes for storage at $-80^{\circ} \mathrm{C}$ until the supernatants were assessed using commercial ELISA assays. PBMC secretion of IFN-gamma was measured using the Bovine IFN-gamma DuoSet kit (RD system ${ }^{\circledR}$, USA), and secretion of IL17 was measured using the Bovine IL-17A ELISA VetSet antibody pair and standard (Kingfisher Biotech $^{\circledR}$, USA). The assays were performed as recommended by the manufactures. Both ELISA assays provided quantitative assessment of the cytokines in $\mathrm{ng} / \mathrm{mL}$ with a validated range of 16$2,000 \mathrm{ng} / \mathrm{mL}$.

\section{Statistical analysis}

Statistical analyses were conducted using SPSS software (IBM SPSS Statistics for Windows, Version 19.0. Armonk, NY: IBM Corp.).

Data was tested for normal distribution using Shapiro-Wilk test. Total lymphocytes and subsets demonstrated a parametric distribution. Therefore, the data was represented as means and standard deviations. Differences between groups were determined at each time point using an unpaired t test. Repeated measure ANOVA coupled with Bonferroni post-hoc test was used to analyze parametric data across time. Differences were considered significant when $\mathrm{P} \leq 0.05\left(^{*}\right)$ or tendency to $\mathrm{P} \leq 0.10(\dagger)$.

Cytokines concentrations showed a non-parametric distribution. Therefore, cytokine data was represented as minimum, median and maximum values. Differences between groups were assessed using the Mann-Whitney $U$ test and considered signifi- 
cant when $\mathrm{P} \leq 0.05(*)$ or tendency to $\mathrm{P} \leq 0.10(\dagger)$. Friedman test was used to identify difference for non-parametric data relative to time $(\mathrm{P} \leq 0.05)$. The multiple comparisons between individual time points of assessment were performed by Wilcoxon test with Bonferroni correction, and significance set at $\mathrm{P} \leq 0.003$.

\section{RESULTS}

\section{Phenotyping}

The mean percentage of cells in each phenotypic subset measured over the course of this study is shown in Figure 1. We measured $\mathrm{CD} 45 \mathrm{RO}^{+}$and $\mathrm{CD}_{3} \mathrm{GD}^{+}$lymphocytes in gates defined by side and granularity. These subpopulations will be referred to as memory lymphocytes when CD45RO ${ }^{+}$ and gamma-delta $\mathrm{T}$ cells when both $\mathrm{CD}^{+}$and positive for the gamma-delta delta chain $\left(\mathrm{GD}^{+}\right)$by flow assessment.

COL- and COL+ calves had a similar percentage of circulating leukocytes expressing $\mathrm{CD} 45 \mathrm{RO}^{+}$cells on $\mathrm{D} 0$ and D2. In contrast, COL- calves showed a rapid increase in the percentage of $\mathrm{CD}_{45 \mathrm{RO}^{+}}$on D7 (COL $+=13.7 \%$; COL- $=24.9 \%$, $\mathrm{P}=0.07$ ). The percentage of CD45RO- cells remained higher for the COL+ calves over the first two weeks of the study.
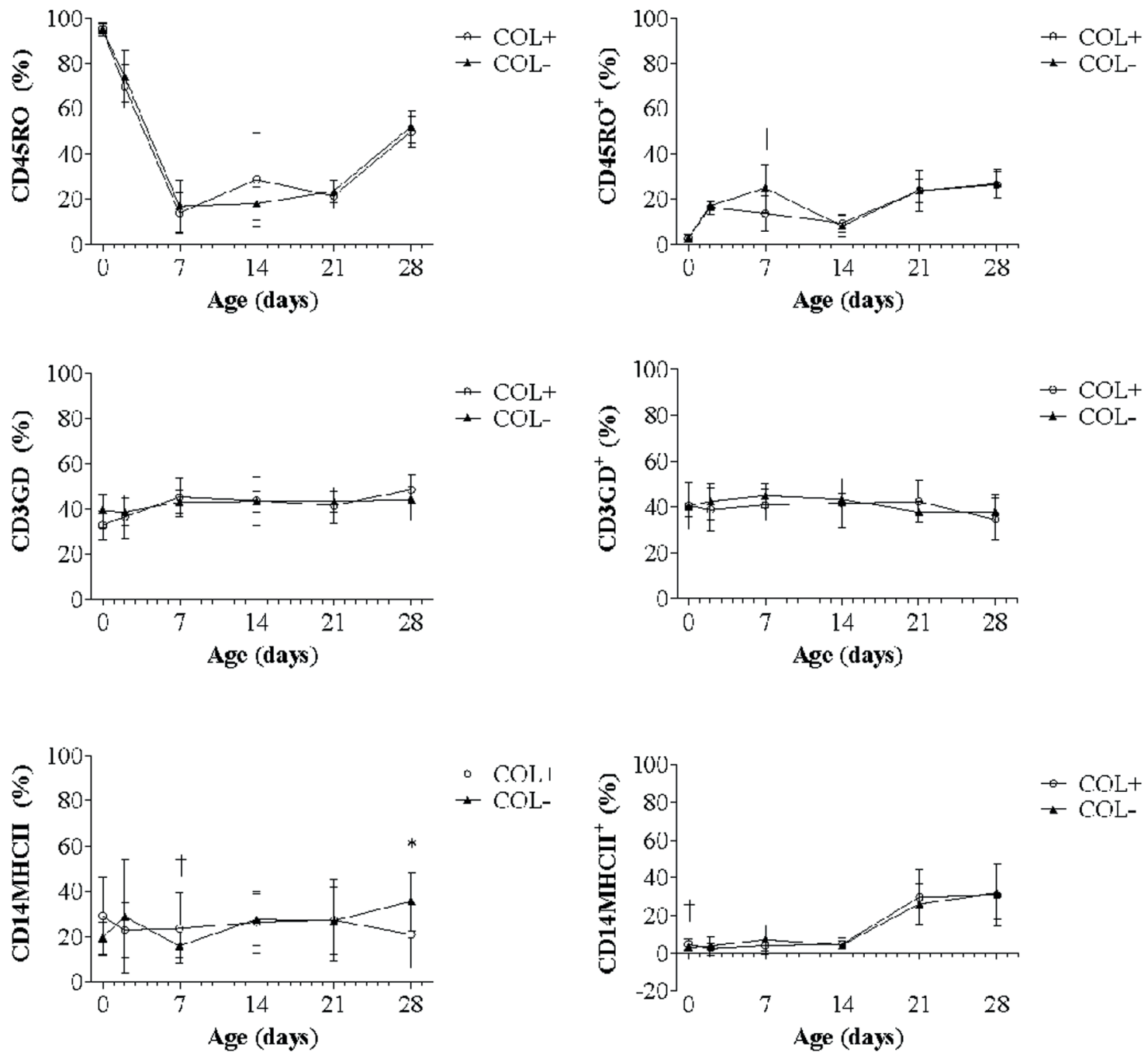

Fig.1. The percent of mononuclear cells of each phenotype indicated in the blood of Holstein calves fed whole colostrum with viable maternal cells (COL+) or frozen colostrum with no viable cells (COL-) at birth over the course of this trial. Significant differences between treatment groups assessed using an unpaired $\mathrm{T}$ test: tendency at $\mathrm{P}<0.05$, * tendency at $\mathrm{P} \leq 0.10$. 
The percentage of CD14MHCII- and CD14 $\mathrm{MHCII}^{+}$mononuclear leukocytes will be referred to as monocytes in this manuscript. CD14MHCII monocytes in COL- calves represented a greater percentage of circulating cells on D28 than for $\mathrm{COL}+$ calves $(\mathrm{COL}+=20.9 \%$; $\mathrm{COL}-=35.4 \%, \mathrm{P}=0.05$ ). No other significant differences between groups were detected in monocytes over the course of this study. A tendency for difference was observed in monocytes (CD14MHCII+) between groups on $\mathrm{D} 0(\mathrm{P}<0.08)$ and $(\mathrm{CD} 14 \mathrm{MHCII})$ between groups on $\mathrm{D} 7(\mathrm{P}<0.09)$. The percentage of circulating $\mathrm{CD} 14 \mathrm{MHCII}^{+}$monocytes increased with increasing age in both treatment groups (COL+: D0 to D14 vs D28 and D2 vs D21; COL-: COL+: D0 to D14 vs D21 and D28; P $\leq 0.05$ ).

\section{Cytokines secretion by PBMC stimulated with Staphylo- coccus aureus and Escherichia coli}

The minimum, median and maximum values for IFN-gamma and IL17 secreted by PBMC after stimulation are shown in Table 2 and 3.

No detectable cytokine was produced by PBMC that were not stimulated in these assessments. In contrast, the PBMC from COL+ calves stimulated with ConA secreted a good deal of IFN-gamma on D14 to D28, essentially no IFN-gamma production was measured in PBMC from COL- calves on D14 through D28. Some IFN-gamma was produced by a few of the COL- calves stimulated with ConA on D14, D21 and D28, but the median value was $0.0 \mathrm{pg} / \mathrm{mL}$. The median value for IFN-gamma for COL+ calves stimulated with ConA on D7 was also $0.0 \mathrm{pg} / \mathrm{mL}$. Similar results were obtained for IL17 with ConA stimulate PBMC from COL+ calves producing median values between 291.0 and 2060.0pg/ $\mathrm{mL}$ of IL-17, but PBMC from COL- calves producing median values between 0.0 and $301.0 \mathrm{pg} / \mathrm{mL}$ across the course of the study. Statistical difference in ConA stimulated IFN-gamma and IL-17 production between the treatment groups was observed on D14 $(\mathrm{P}=0.00)$. PBMC stimulated with ConA from both treatment groups produced comparable amounts of IL17 on D7.

PBMC from COL- calves stimulated with S.aureus secreted more IFN-gamma on D21 than PBMC from COL+ calves (median of COL $+=0.0 \mathrm{pg} / \mathrm{mL}$ and $\mathrm{COL}-=1370.0 \mathrm{pg} / \mathrm{mL}$ ). However, the results were not statistical significant $(\mathrm{P}=0.35)$. PBMC from COL+ calves stimulated with $S$. aureus produced significantly larger quantities of IL17 on D28 (median

Table 1. Monoclonal antibodies for characterization of neonatal leukocytes

\begin{tabular}{lcccccc}
\hline Monoclonal antibodies (Ab)* & Isotype & Specificity & Clone & Dilution & 2nd Ab** & Dilution \\
\hline Mouse anti-bovine CD45 & IgG2a & Total leukocytes & CACTB51A & $1: 50$ & FITC & $1: 100$ \\
Mouse anti-bovine CD45RO & IgG1 & Memory T cells & GC42A & $1: 100$ & PE & $1: 100$ \\
Mouse anti-bovine CD3 & IgG1 & Total T cells & MM1A & $1: 25$ & PE & $1: 100$ \\
Mouse anti-bovine & IgG2b & Gamma-delta T cells & GB21A & $1: 25$ & FITC & $1: 50$ \\
GAMMA DELTA & & (delta chain specific) & & & & \\
Mouse anti-bovine CD14 & IgG1 & Monocytes, B cells & MM61A & $1: 100$ & PE & $1: 100$ \\
Mouse anti-bovine MHCII & IgG2a & B cells and APC & TH16A & $1: 50$ & FITC & $1: 25$ \\
Source: ${ }^{*}$ Washington State University, & ** Invitrogen. FITC = Fluorescein isothiocyanate, PE = Phycoerythrin.
\end{tabular}

Table 2. Minimum, median and maximum values for the concentrations of IFN-gamma secreted by PBMC from neonate calves fed fresh colostrum with viable maternal cells (COL+) and frozen colostrum with no viable cells (COL-)

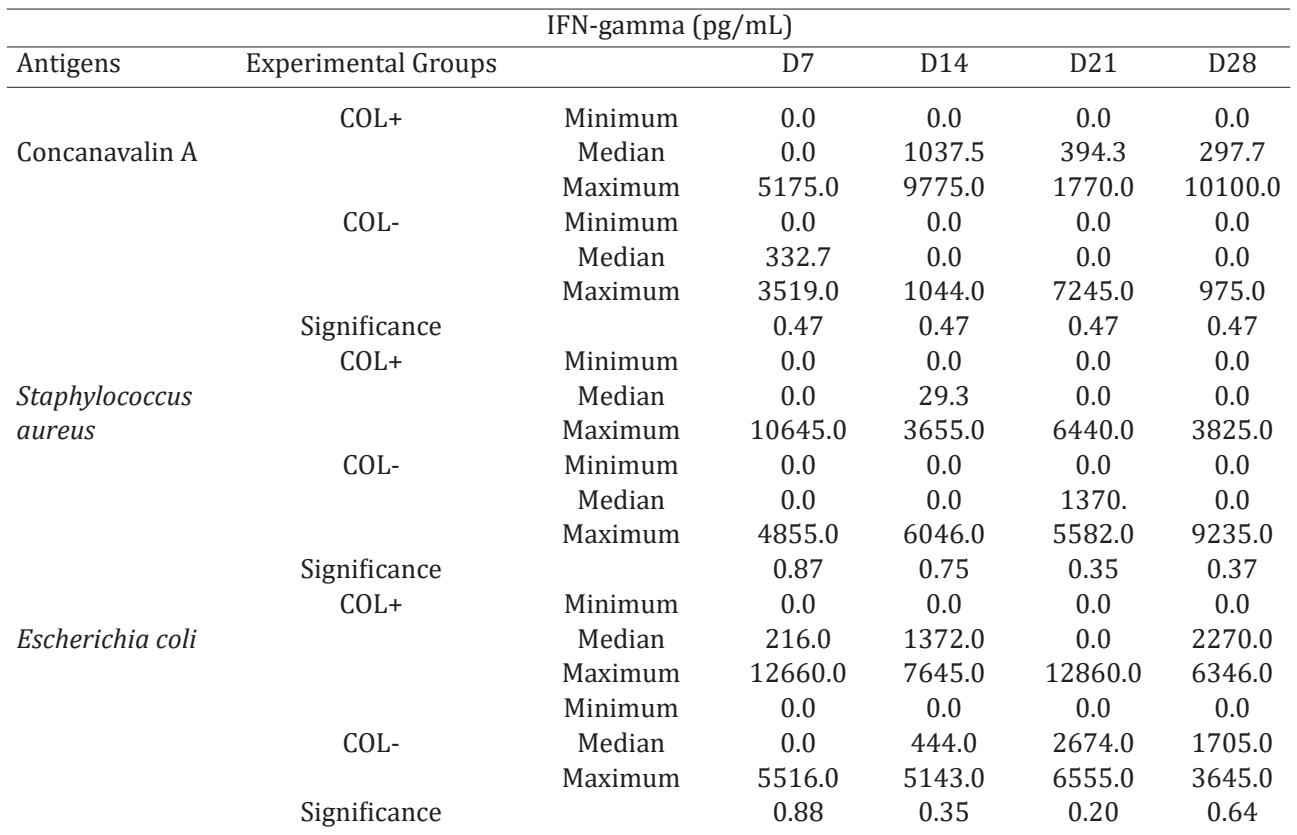

The unstimulated control cells did not secrete IFN-gamma during the course of the experiment. 
Table 3. Minimum, median and maximum values for the concentrations of IL17 cytokines secreted by PBMC from neonate calves fed fresh colostrum with viable maternal cells (COL+) and frozen colostrum with no viable cells (COL-)

\begin{tabular}{|c|c|c|c|c|c|c|}
\hline \multicolumn{7}{|c|}{ IL17 (pg/mL) } \\
\hline Antigens & Experimental Groups & & D7 & D14 & D21 & D28 \\
\hline \multirow{8}{*}{ Concanavalin A } & COL+ & Minimum & 0.0 & 46.9 & 0.0 & 0.0 \\
\hline & & Median & 291.0 & 2060.0 & 325.0 & 2031.0 \\
\hline & & Maximum & 4792.0 & 3967.0 & 1845.0 & 5884.0 \\
\hline & COL- & Minimum & 0.0 & 0.0 & 0.0 & 0.0 \\
\hline & & Median & 215.0 & 0.0 & 0.0 & 301.0 \\
\hline & & Maximum & 5128.0 & 1752.0 & 887.0 & 2107.0 \\
\hline & Significance & & 0.75 & 0.00 & 0.12 & 0.22 \\
\hline & COL+ & Minimum & 0.0 & 0.0 & 0.0 & 0.0 \\
\hline \multirow{7}{*}{$\begin{array}{l}\text { Staphylococcus } \\
\text { aureus }\end{array}$} & & Median & 0.0 & 286.0 & 0.0 & 49.0 \\
\hline & & Maximum & 3754.0 & 1649.0 & 1867.0 & 1417.0 \\
\hline & COL- & Minimum & 0.0 & 0.0 & 0.0 & 0.0 \\
\hline & & Median & 93.0 & 194.0 & 0.0 & 0.0 \\
\hline & & Maximum & 821.0 & 3360.0 & 470.0 & 349.0 \\
\hline & Significance & & 0.60 & 0.69 & 0.44 & 0.05 \\
\hline & COL+ & Minimum & 0.0 & 352.4 & 0.0 & 0.0 \\
\hline \multirow[t]{6}{*}{ Escherichia coli } & & Median & 14.0 & 828.0 & 0.0 & 562.0 \\
\hline & & Maximum & 1888.0 & 2303.0 & 1772.0 & 2230.0 \\
\hline & COL- & Minimum & 0.0 & 0.0 & 0.0 & 0.0 \\
\hline & & Median & 521.0 & 581.0 & 0.0 & 0.0 \\
\hline & & Maximum & 39450.0 & 4146.0 & 600.0 & 772.0 \\
\hline & Significance & & 0.16 & 0.37 & 0.63 & 0.05 \\
\hline
\end{tabular}

The unstimulated control cells did not secrete IL-17 during the course of the experiment.

$\mathrm{COL}+=49.0 ; \mathrm{COL}-=0.0 \mathrm{pg} / \mathrm{mL}, \mathrm{P}=0.05$ ) than PBMC from COL- calves.

PBMC from COL- calves stimulated with E.coli secreted measurable levels of IFN-gamma on D21, but PBMC from COL+ calves did not (median COL $+=0.0$ COL $-=2674.0 \mathrm{pg} /$ $\mathrm{mL}$ ). The observed difference was not statistical different $(\mathrm{P}=0.20)$. PBMC from COL+ calves stimulated with $E$. coli produced a significantly higher concentration of IL17 on D28 (COL+=562.0; $\mathrm{COL}-=0.0 \mathrm{pg} / \mathrm{mL}, \mathrm{P}=0.05$ ) than PBMC from COL- calves.

\section{DISCUSSION}

This research assessed the influence of viable maternal cells, transferred with fresh whole colostrum, on the development of immunity in calves during the first 28 days of life. This study focused on the phenotypic expression of memory associated to antigen (CD45RO), the percentage of cells with a phenotype consistent with that established for antigen presenting cells (APC; $\mathrm{CD} 14^{+}$cells that also express MHC class II), the change in the percentage of circulating gamma-delta T cells, and the capacity of the circulating mononuclear cells to produce IFN-gamma and IL17 when stimulated with ConA, killed Staphylococcus aureus and killed Escherichia coli whole cell antigens.

The percentage of naïve monocytes (CD14 ${ }^{+} \mathrm{MHC}$ class $\left.\mathrm{II}^{-}\right)$and activated monocytes moving toward APC function $\left(\mathrm{CD} 14^{+} \mathrm{MHC}\right.$ class $\left.\mathrm{II}^{+}\right)$in the blood increased in the COLcalves on D2. In this experiment, calves from both groups were raised at the same site and under the same management practices, except for the initial feeding of colostrum. As extra time was required to thaw frozen colostrum from the pool to feed calves from COL-group, the delay in feeding may have generated stress which would likely increase in the number of circulating monocytes (CD14 $4^{+}$in the COLcalves due to higher levels of cortisol (Davis et al. 2008).

Additional differences between groups were observed for naïve monocytes CD14MHCII on D7 and D28 of this study. COL- calves had a higher percentage of circulating naïve monocytes CD14MHCII than the COL+ calves on D7. The percentage of APC was similar between the two treatments over the course of the study. In contrast to our findings, other researchers have reported that COL+ calves had a higher percentage of circulating cells with a phenotype consistent with developing APC (Reber et al. 2005, 2008a, 2008b).

The percentage of cells with an APC phenotype increased over the course of this study. This was most remarkable after onset of diarrhea disease (D7-D14) in the circulation of calves from both treatment groups. Thus, there appeared to be a similar natural exposure to environmental pathogens that directly influenced the dynamics of naïve monocytes leaving the bone marrow and the differentiation of monocytes toward becoming functional APC.

The percentage of gamma-delta $\mathrm{T}$ cells was not different between the two treatment groups over the course of this study. The percentage of gamma-delta $\mathrm{T}$ cells $\left(\mathrm{CD} 3+\mathrm{GD}^{+}\right)$in neonate calves is typically between $25-40 \%$ (Wilson et al. 1996). Many functions have been ascribed to gamma delta $\mathrm{T}$ cells in cattle, mice and humans, including cytokine production, antigen presentation, and immune regulation (Guzman et al. 2012, 2014). Gamma-delta T cells contribute to the production of IL-17 in the development of early immune responses to Mycobacteria and respiratory disease caused by BRSV and Mannheimia (McGill et al. 2014, 2016). In addition, it has been reported that gamma-delta $\mathrm{T}$ cells also produce IFN-gamma as the immune response 
at the tissue level matures. In this study, an antibody that recognizes a constant domain of the delta chain was utilized rather than one of the more commonly utilized WC1 antibodies. This means that all of the gamma-delta $\mathrm{T}$ cells in circulation were monitored rather than the more limited subset identified as WC1. The full complement of gamma-delta cells represents all of the described activities for these cells, including their APC and cytokine producing roles. As calves from both treatment groups demonstrated early IL-17 production followed by the capacity to produce IFN-gamma, the data from this project is relatively consistent with the earlier reports by McGill et al. $(2014,2016)$. Still, the function of the high number of gamma-delta cells in neonate calves needs to be better defined in future studies.

The influence of viable maternal cells in colostrum on the percentage of $\mathrm{CD} 45 \mathrm{RO}^{+}$memory lymphocytes in neonate was assessed. $\mathrm{CD} 45 \mathrm{RO}^{+}$is a cell surface glycoprotein expressed strongly after activation of T lymphocytes (Sallusto et al. 1999). COL- and COL+ calves both showed a similar percentage of memory lymphocytes over the duration of this study. Langel et al. (2015) reported higher absolute number and percentage of $\mathrm{CD} 4^{+} \mathrm{CD} 62 \mathrm{~L}^{-} \mathrm{CD} 45 \mathrm{RO}^{+}$in calves fed with whole than cell-free colostrum on d7. This corresponds well with our findings.

COL- calves had more CD45RO ${ }^{+}$cells on $\mathrm{D} 7(\mathrm{COL}+=13.7$; COL- $=24.9 \%, \mathrm{P}=0.07$ ) than COL+. This difference was not significant, but suggests that early interaction with pathogens may have lead to an increase in circulating cells from the developing secondary lymphoid tissue after primary activation. The larger percentage of lymphocytes expression $\mathrm{CD}_{4} 5 \mathrm{RO}^{+}$in COL- calves may be facilitated by the more severe diarrhea in calves fed frozen colostrum with out viable maternal cells that produced circulating memory cells after mucosal exposure and immune response priming.

The calves from both groups had a low percentage of $\mathrm{CD}^{2} 5 \mathrm{RO}^{+}$lymphocytes at birth (D0). The percentage of $\mathrm{CD}^{2} 5 \mathrm{RO}^{+}$cells increased in both group over the course of the study. This probably reflects the activation of naïve $T$ cells in mucosal organized lymphoid tissues, or the developing secondary lymphoid organs, seeded by the presence of viable maternal cells that trafficked in the circulation and took up residence (Aldridge et al. 1998, Reber et al. 2006). In addition, more than $80 \%$ of quarters from heifers within 2 months of delivery of their fist calf were routinely colonized with bacteria, primarily CNS. Therefore, transfer of bacteria with colostrum may be a mechanism by which cows stimulate immune development in neonate calves (Ryman et al. 2013, Nace et al. 2014, Harding et al. 2015). In humans there are several reports that breast milk contribute to gut colonization and immune stimulation in infants, e.g. Perez et al. (2007).

The percentage of $\mathrm{CD} 45 \mathrm{RO}^{+}$memory lymphocytes increased on D21 and D28 in this study. Langel et al. (2015) also found higher percentage of CD4+CD62 $\mathrm{L}^{-} \mathrm{CD} 45 \mathrm{RO}^{+}$lymphocytes on D28 in their study. This finding indicates the development of an active immune response in the calves during the first month after delivery, a time when they are considered most naïve. The development of active immunity appears to be due to interaction with environmental microorganisms. The best documented interactions enhancing immune development are on mucosal surfaces. The high incidence of diarrheal disease observed in this study oD7 and D14 certainly fits that model (Chase et al. 2008).

In general, the phenotypic profile of circulating leukocytes did not indicate the transfer of maternal CD45RO ${ }^{+}$ memory cells or $\mathrm{CD} 14^{+} \mathrm{MHCII}^{+}$primed APC associated with colostrum intake. Our findings are in contrast to those of Reber et al. (2005, 2008a, 2008b) and Langel et al. (2015).

This experiment was conduced on one farm. It utilized a single genetic improvement program for all cows, one standard management protocol, and equivalent housing, diet, comfort, welfare and vaccination schedules for the dams during the transition period. Moreover, each delivery was monitored to assure that only calves from uncomplicated deliveries that were healthy at birth were included.

One difficulty in the design of this experiment was in our ability to standardize the composition of the colostrum. It was necessary use different cows as the source for fresh colostrum and the pool of frozen colostrum to fed COL+ and COL- calves. However, the components of colostrum that were measured for quality purposes (IgG, total protein, total solids and the presence of viable cells) demonstrated very high similarity between the colostrum received for each group, except for the presence of viable maternal cells (Costa et al. 2017). The small number of calves in each group also made it difficult to provide strong statistical evidence of the hypothesis tested in this study. This is a problem common to almost all studies in this area of research.

COL- heifers has more severe diarrhea in response to the environmental pathogens. The analysis of the innate immune response of these calves demonstrated that COLmounted an innate response more slowly than $\mathrm{COL}+$ calves that yielded a persistent inflammatory response after exposure to these bacteria agents (Costa et al. 2017).

The adaptive immune response to bacterial antigens was evaluated by ex vivo induction of cytokines secretion by PBMC stimulated with killed S. aureus and killed E.coli whole cell antigen. These bacteria were selected because dams are repeated exposed to them over their lifetime in the environment of the farm where the research was done.

Unstimulated PBMC did not secrete IFN-gamma or IL17 in any of the assays preformed. PBMC from COL+ calves secreted large amounts of IFN-gamma (D14) and of IL-17 (D14 and D28) after stimulation with ConA. ConA is a widely used mitogen that stimulates clonal expansion of about $40 \%$ of lymphocytes, and strong production of many cytokines. Reber et al. (2005) reported high proliferative response of PBMC in response after stimulation with the superantigen, Staphylococcus enterotoxin B (SEB) by PBMC from $\mathrm{COL}+$ calves during the first three weeks after birth.

PBMC from COL- calves stimulated with killed $S$. aureus whole cell antigen and killed $E$. coli whole cell antigen produced high levels of IFN-gamma on D21. In contrast, PBMC from COL+ stimulated with the same antigens secreted high concentrations of IL17 and IFN-gamma on D14 and D28.

IL17 is a cytokine that plays an important role in orchestrating innate immune function. This cytokine induces 
neutrophil recruitment and activation (Roark et al. 2008, Garraud et al. 2012, Taylor et al. 2014). The enhanced IL17 production reported here could be responsible for the rapid recruitment of neutrophils to mediate bacterial clearance observed in the COL- group, reported by Costa et al. (2017).

However, this research provides a little indication for a differential role of maternal cells in the development of the cytokine response in calves in this experiment.

\section{CONCLUSIONS}

Calves fed fresh colostrum with viable maternal cells or frozen colostrum with no viable maternal cells had a similar phenotypic of circulating cells subsets at birth and during the first week of the study.

Enhanced evidence of memory lymphocytes and monocytes with a phenotype indicating development of APC capacity were observed in both treatment groups over the course of the study.

Enhanced IL17 secretion by COL+ calves indicated that maternal cells modulated Th17 responses that were required to kill bacteria in mucosal tissues and may have been responsible for the differential severity of diarrheal disease seen between the two treatment groups.

Acknowledgements.- This study was supported by grants from National Counsel of Technological and Scientific Development [grant numbers 2013/06152-7, 2013/02484-5]. In addition, we are indebted to the Colorado farm crew for their assistance in the performance of this project.

\section{REFERENCES}

Aldridge B.M., McGuirk S.M. \& Lunn D.P. 1998. Effect of colostral ingestion on immunoglobulin-positive cells in calves. Vet. Immunol. Immunopathol. 62(1):51-64.

Barrington G.M. \& Parish S.M. 2001. Bovine Neonatal Immunology. Vet. Clin. N. Am., Food Anim. Pract. 17(3):463-476.

Chase C.C.L., Hurley D.J. \& Reber A.J. 2008. Neonatal immune development in the calf and its impact on vaccine response. Vet. Clin. N. Am., Food Anim. Pract. 24(1):87-104.

Costa J.F.R., Novo S.M.F., Baccili C.C., Sobreira N.M., Hurley D.J. \& Gomes V. 2017. Innate immune response in neonate Holstein heifer calves fed fresh or frozen colostrum. Res. Vet. Sci. 115:54-60.

Davis A.K., Maney D.L. \& Maerz J.C. 2008. The use of leukocyte profiles to measure stress in vertebrates: a review for ecologists. Funct. Ecol. 22(5):760-772.

Donovan D.C., Reber A.J., Gabbard J.D., Aceves-Avila M., Galland K.L., Holbert K.A., Ely L.O. \& Hurley D.J. 2007. Effect of maternal cells transferred with colostrum on cellular responses to pathogen antigens in neonatal calves. Am. J. Vet. Res. 68(7):778-782.

Garraud K., Cleret A., Mathieu J., Fiole D., Gauthier Y., Quesnel-Hellmann A. \& Tournier J.N. 2012. Differential role of the interleukin-17 axis and neutrophils in resolution of inhalational anthrax. Infect. Immun. 80(1): 131-142.

Godden S.M., Smolenski D.J., Donahue M., Oakes J.M., Bey R., Wells S., Sreevatsan S., Stabel J. \& Fetrow J. 2012. Heat-treated colostrum and reduced morbidity in preweaned dairy calves: Results of a randomized trial and examination of mechanisms of effectiveness. J. Dairy Sci. 95(7):40294040 .

Gomes V., Madureira K.M., Della Libera A.M.M.P., Blagitz M.G., Alves M., Baptistella F. \& Benesi F.J. 2011. Dinâmica da celularidade do colostro de vacas holandesas no pós-parto imediato. Arq. Bras. Med. Vet. Zootec. 63:1047-1053.

Guzman E., Price S., Poulsom H. \& Hope J. 2012. Bovine $\gamma \delta$ T cells: cells with multiple functions and important roles in immunity. Vet. Immunol. Immunopathol. 148(1):161-167.

Guzman E., Hope J., Taylor G., Smith A.L., Cubillos-Zapata C. \& Charleston B. 2014. Bovine $\gamma \delta$ T cells are a major regulatory T cell subset. J. Immunol. 193(1):208-222.

Harding A., Nickerson S.C., Kautz F., Ely L. \& Hurley D.J. 2015. Maximizing heifers' udder health. Hoard's Dairyman, Milk Quality 10 Oct. 2015.

Langel S.N., Wark W.A., Garst S.N., James R.E., McGilliard M.L., Petersson-Wolfe C.S. \& Kanevsky-Mullarky I. 2015. Effect of feeding whole compared with cell-free colostrum on calf immune status: The neonatal period. J. Dairy Sci. 98(6):3729-3740.

Liebler-Tenorio E.M., Riedel-Gasparin G. \& Pohlenz J.F. 2002. Uptake of colostral leukocytes in the intestinal tract of newborn calves. Vet. Immunol. Immunopathol. 85(1):33-40.

McGill J.L., Sacco R.E., Baldwin C.L., Telfer J.C., Palmer M.V. \& Waters W.R. 2014. The role of gamma delta $\mathrm{T}$ cells in immunity to Mycobacterium bovis infection in cattle. Vet. Immunol. Immunopathol. 159(3):133-143.

McGill J.L., Rusk R.A., Guerra-Maupome M., Briggs R.E. \& Sacco R.E. 2016. Bovine Gamma Delta T Cells Contribute to Exacerbated IL-17 Production in Response to Co-Infection with Bovine RSV and Mannheimia haemolytica. PloS one. 11(3):1-20.

Meganck V., Goddeeris B.M., Stuyven E., Piepers S., Cox E. \& Opsomer G. 2014. Development of a method for isolating bovine colostrum mononuclear leukocytes for phenotyping and functional studies. Vet. J. 200(2):294-298.

Nace L., Nickerson S.C., Kautz F.M., Breidling S., Wochele D., Ely L.O. \& Hurley D.J. 2014. Modulation of innate immune function and phenotype in bred dairy heifers during the periparturient period induced by feeding an immunostimulant for 60 days prior to delivery. Vet. Immunol. Immunopathol. 161(3):240-250.

Novo S.M.F., Costa J.F.R., Baccili C.C., Sobreira N.M., Silva B.T., Oliveira P.L., Hurley D.J. \& Gomes V. 2017. Effect of maternal cells transferred with colostrum on the health of neonate calves. Res. Vet. Sci. (In publication)

Perez P.F., Doré J., Leclerc M., Levenez F., Benyacoub J., Serrant P., Roggero I.S., Schiffrin E.J. \& Hughes A.D. 2007. Bacterial imprinting of the neonatal immune system: lessons from maternal cells? Pediatrics 119(3):724e732.

Reber A.J., Hippen A.R. \& Hurley D.J. 2005. Effects of the ingestion of whole colostrum or cell-free colostrum on the capacity of leukocytes in newborn calves to stimulate or respond in one-way mixed leukocyte cultures. Am. J. Vet. Res. 66(11):1854-1860.

Reber A.J., Lockwood A., Hippen A.R. \& Hurley D.J. 2006. Colostrum induced phenotypic and trafficking changes in maternal mononuclear cells in a peripheral blood leukocyte model for study of leukocyte transfer to the neonatal calf. Vet. Immunol. Immunopathol. 109(1):139-150.

Reber A.J., Donovan D.C., Gabbard J., Galland K., Aceves-Avila M., Holbert K.A., Marshall L. \& Hurley D.J. 2008a. Transfer of maternal colostral leukocytes promotes development of the neonatal immune system Part I. Effects on monocyte lineage cells. Vet. Immunol. Immunopathol. 123(3):186-196.

Reber A.J., Donovan D.C., Gabbard J., Galland K., Aceves-Avila M., Holbert K.A., Marshall L. \& Hurley D.J. 2008b. Transfer of maternal colostral leukocytes promotes development of the neonatal immune system Part II. Effects on neonatal lymphocytes. Vet. Immunol. Immunopathol. 123(3):305-313.

Riedel-Caspari G. \& Schmidt F.W. 1991a. The influence of colostral leukocytes on the immune system of the neonatal calf. I. Effects on lymphocyte responses. Dtsch. Tierärztl. Wochenschr. 98(3):102-107.

Riedel-Caspari G. \& Schmidt F.W. 1991b. The influence of colostral leukocytes on the immune system of the neonatal calf. II. Effects on passive and active immunization. Dtsch. Tierärztl. Wochenschr. 98(5):190-194.

Riedel-Caspari G. \& Schmidt F.W. 1991c. The influence of colostral leukocytes on the immune system of the neonatal calf. III. Effects on phagocytosis. Dtsch. Tierärztl. Wochenschr. 98(9):330-334.

Riedel-Caspari G. \& Schmidt F.W. 1991d. The influence of colostral leukocytes on the immune system of the neonatal calf. IV. Effects on bacteri- 
cidity, complement and interferon; synopsis. Dtsch. Tierärztl. Wochenschr. 98(10):395-398.

Roark C.L., Simonian P.L., Fontenot A.P., Born W.K. \& O’Brien R.L. 2008. $\gamma \delta$ T cells: an important source of IL-17. Curr. Opin. Immunol. 20(3):353-357.

Ryman V.E., Nickerson S.C., Hurley D.J., Berghaus R.D. \& Kautz F.M. 2013. Influence of horn flies (Haematobia irritans) on teat skin condition, intramammary infection, and serum anti-S. aureus antibody titers in Holstein heifers. Res. Vest. Sci. 95(2):343-346.

Sallusto F., Lenig D., Förster R., Lipp M. \& Lanzavecchia A. 1999. Two sub- sets of memory $\mathrm{T}$ lymphocytes with distinct homing potentials and effector functions. Nature 401(6754):708-712.

Taylor P.R., Roy S., Leal Jr S.M., Sun Y., Howell S.J., Cobb B.A., Li X. \& Pearlman E. 2014. Activation of neutrophils by autocrine IL-17A-IL-17RC interactions during fungal infection is regulated by IL-6, IL-23, ROR [gamma] $t$ and dectin-2. Nat. Immunol. 15(2):143-151.

Wilson R.A., Zolnai A., Rudas P. \& Frenyo L.V. 1996. T-cell subsets in blood and lymphoid tissues obtained from fetal calves, maturing calves, and adult bovine. Vet. Immunol. Immunopathol. 53(1):49-60. 